\title{
Orthographic Comparison
}

This study tries to uncover the linguistic features of Quranic Arabic by focusing on the earliest layer of the written text, Quranic Consonantal Text. This is the standard philological approach to studying languages of antiquity, but doing this to the Quran is not without its problems. As of writing, there is no critical edition of the Quranic text, and the field generally relies on the standard text established by the Cairo Edition. This edition is by no means a poor edition, as its orthography is explicitly archaizing. It has attempted to reconstructed the original Uthmanic rasm as much as possible by relying on medieval rasm works such as al-Dānīs muqniS. As a result, much of how the orthography is presented in this edition is a fairly accurate representation of what $5^{\text {th }}$ century AH sources reported about manuscripts that predated them by yet another couple of centuries.

Comparison with Quranic manuscripts shows that these descriptions indeed are fairly reliable guides to the orthography as it appears in the earliest manuscripts. However, they are not always accurate, and throughout this work I have sometimes had to draw upon the orthographic practices as they appear in early manuscripts rather than how they appear in the CE. When I do so, I refer to entries in this Appendix, which presents tables of certain important lexical items and it examines how they appear in early manuscripts. These comparative tables will function as "critical editions" not of the full Quranic text, but of the individual specific words that are being examined.

From the following tables it will quickly become clear that, most of the time the manuscript records show a remarkably consistent picture, all sharing the same spelling with only the occasional exception. Not infrequently, the Cairo Edition is the odd one out. When such a consistent picture emerges, there can be little doubt that what we find in these manuscripts can be confidently reconstructed for the archetype, despite the Cairo Edition showing something different.

Throughout this appendix, I have consistently drawn on several manuscripts to see if the relevant words occur in these. The abbreviations that I use in the tables are given here. On occasion it has been relevant to cite other manuscripts, in which case I will discuss them individually below the relevant table. Unless stated otherwise I have accessed these manuscripts in digitized form, using the Corpus Coranicum (http://www.corpuscoranicum.de) and Gallica (http://gallica.bnf.fr) websites. 
The selection of the manuscripts consulted is based to a large extent on availability. All of these manuscripts contain a significant portion of the Quranic text, and a good number of them are considerably early. Several of the ones consulted (especially GK, S, M-Ali, and S-Ali) are probably to be dated somewhat later than the other manuscripts consulted here. These, however, are rather complete examples, and therefore frequently allow us to establish what the orthography continued to look like in later manuscripts (more often than not, there is hardly a difference between earlier and later manuscripts in this regard).

1615I Dublin, Chester Beatty Library, Is 1615 I + Doha, Museum of Islamic Art Ms. 68.2007, Ms. 69.2007, Ms. 70.2007, Ms. 699.2007 + Houston, Vahid Kooris Private Collection

47 folios; ${ }^{14} \mathrm{C}$ : $591-643 \mathrm{CE}, \sigma_{2}$ (95.4\%); "33og style"

I have only been able to access the folios of the CBL.

33 og Paris, Bibliothèque nationale de France, Arabe $33 \circ \mathrm{og}+$ Dublin, Chester Beatty Library, Is 1615 II + St. Petersburg, National Library, Marcel 16 + Manama, Bayt al-QurPān, Ms. 1611-MKH235 + auctioned folios: Rennes Enchères 2011, Lot 151

43 folios; first century; " 33 og style"

I have only been able to access the folios of the BnF and СBL.

331 Paris, Bibliothèque nationale de France, Arabe 331 + Leiden, Leiden University Library, Or. 14.545 b + c

58 folios; first century, ${ }^{14} \mathrm{C}$ : $65^{2-76} 3 \mathrm{CE}, \sigma_{2}$ (95.4\%); Kufi B Ia (Déroche 1983,67, no. 14).

BL London, British Library, Or. 2165 + Paris, Bibliothèque nationale de France, Arabe 328e + Kuwait, Dār al-Rātāār al-Pislāmiyyah, LNS 19 CA $^{\text {ab }}$ (bifolio)

128 folios; second half of the first century (Dutton 2004, 66); Hijazi II (Déroche 1983, 62, no. 7).

Reading of LNS folio is based on the transcription on the Corpus Coranicum website. Or. 2165 has been accessed from the British Library website and the Parisian section on Gallica.

ca1 Codex Amrensis 1

75 folios; ca. first half second century(?) (Cellard 2018, 15); Late Hijazi (Cellard 2018, 7)/Hijazi I (Déroche 1983, 59, no. 1).

Edited and published by Cellard (2018).

CPP Codex Parisino-Petropolitanus

98 folios; c. third quarter of the first/seventh century (Déroche 20o9, 177); Hijazi I (Déroche 1983, 59 f., nos. 2 \& 3). 
Edited and published by Déroche (2009). For the Parisian folios I have checked these myself through the digitizations available on the Corpus Coranicum and Gallica websites. For the other folios, I have relied on Déroche's transcriptions.

D29 Sanaa, Dār al-Maxṭūtāt, DAM o1-29.1

35 folios; ca. 1st century. Various styles: Hijazi I, Kufi B.Ia.

I have had private access to these folios, as I am currently preparing an edition of this manuscript together with Michael Marx.

GK Kairo, al-Maktaba al-Markaziyya li-l-Maxṭūtāt al-Pislāmiyyah: Großer Korankodex

1087 folios; not before 70o; Kufi B.Ib or B.II.

M-Ali The Mashhad codex attributed to Saliyy b. Rabī Ṭālib

341 folios; ca. 2nd/3rd century; Kufi B.II.

Edited and published by Altıkulaç et al. (2017)

Q Cairo, Dār al-Kutub Ms 247 (Qaf 47) + Berlin, Staatsbibliothek, Ms. Or. Fol. 4313

36 folios; first century, ${ }^{14} \mathrm{C}$ : 6o6-652, $\sigma_{2}$ (95.4\%) (Marx and Jocham 2015); "33og style"

S Berlin, Staatsbibliothek: Samarkand Codex (Facsimile) 353 folios; ca. 750-85o. Kufi D I.

S-Ali al-Muṣhaf al-Sharīf attributed to 'Alī b. Abī Ṭālib (the copy of Sana'a) 275 folios; ca. 2 nd/3rd century. Kufi C.III. ${ }^{1}$

Edited and published by Altıkulaç (2011).

sM1a Gotthelf-Bergsträßer Archive: Saray Medina 1a

308 folios; late first/early second century; various styles: Hijazi, B.Ia, O.I.

SM1b Gotthelf-Bergsträßer Archive: Saray Medina 1b 134 folios; 2nd/3rd century; C.III.

SU = Codex Șanāà I, upper text Sanaa Dār al-Maxṭuṭāt, DAM o1-27.1 + Ḥamdūn (2004) + auctioned folios: Christie's 2008; Bonhams 20oo; Sotheby's 1992 and Sotheby's 1993.

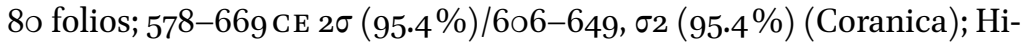
jazi I.

The upper text of the Sanaa palimpsest must of course post-date the lower text, but can still be considered an early Quranic manuscript from the first or early second century on the basis of its orthography.

1 For an approximate dating of the C.III style see Cellard $(2015,212)$. 
T Tübingen, Universitätsbibliothek, Ma vi 165 77 folios; ${ }^{14} \mathrm{C}: 649-675, \sigma 2$ (95.4\%); Kufi B.Ia.

Top Istanbul, Topkapı Sarayı Müzesi: H.S. 44.31 408 folios. Late first/seventh, early second/eight century; Kufi C.I Edited and published by Altıkulaç (2007).

W Berlin, Staatsbibliothek: Wetzstein II 1913 (Ahlwardt 305) + BnF Arabe $6 \circ 87$.

216 folios.; Second half first century/early second century, ${ }^{14} \mathrm{C}: 662-765$, $\sigma_{2}$ (95.4\%); Kufi B/ra (Déroche 1983, 67, no. 160).

In some cases, some changes have been made in manuscripts to the relevant word that is being considered. The following symbols are used in the following:

(...) letter added later.

$\{\ldots\} \quad$ letter removed.

[...] absent in the text.

س w w w w w w w w w w 


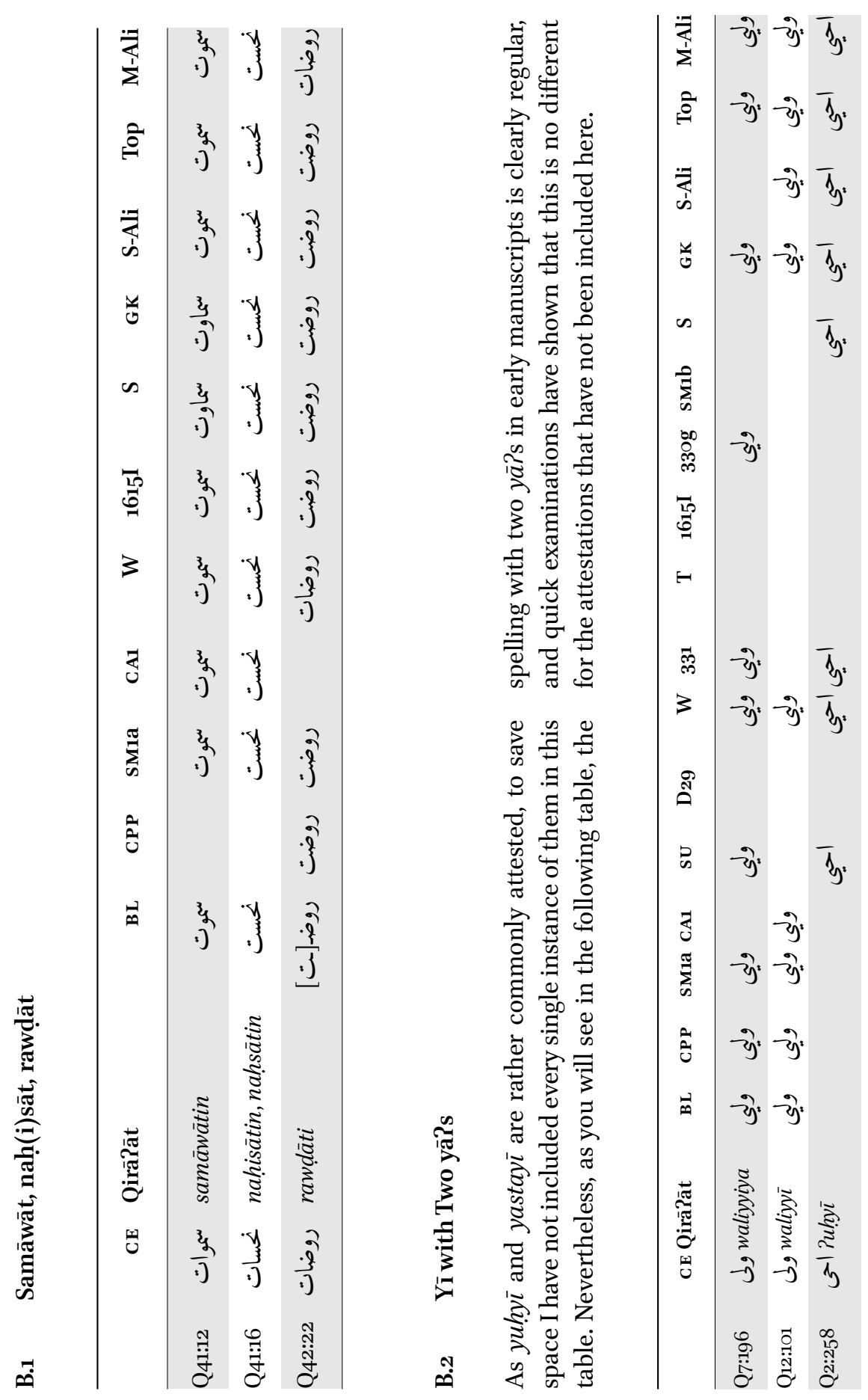



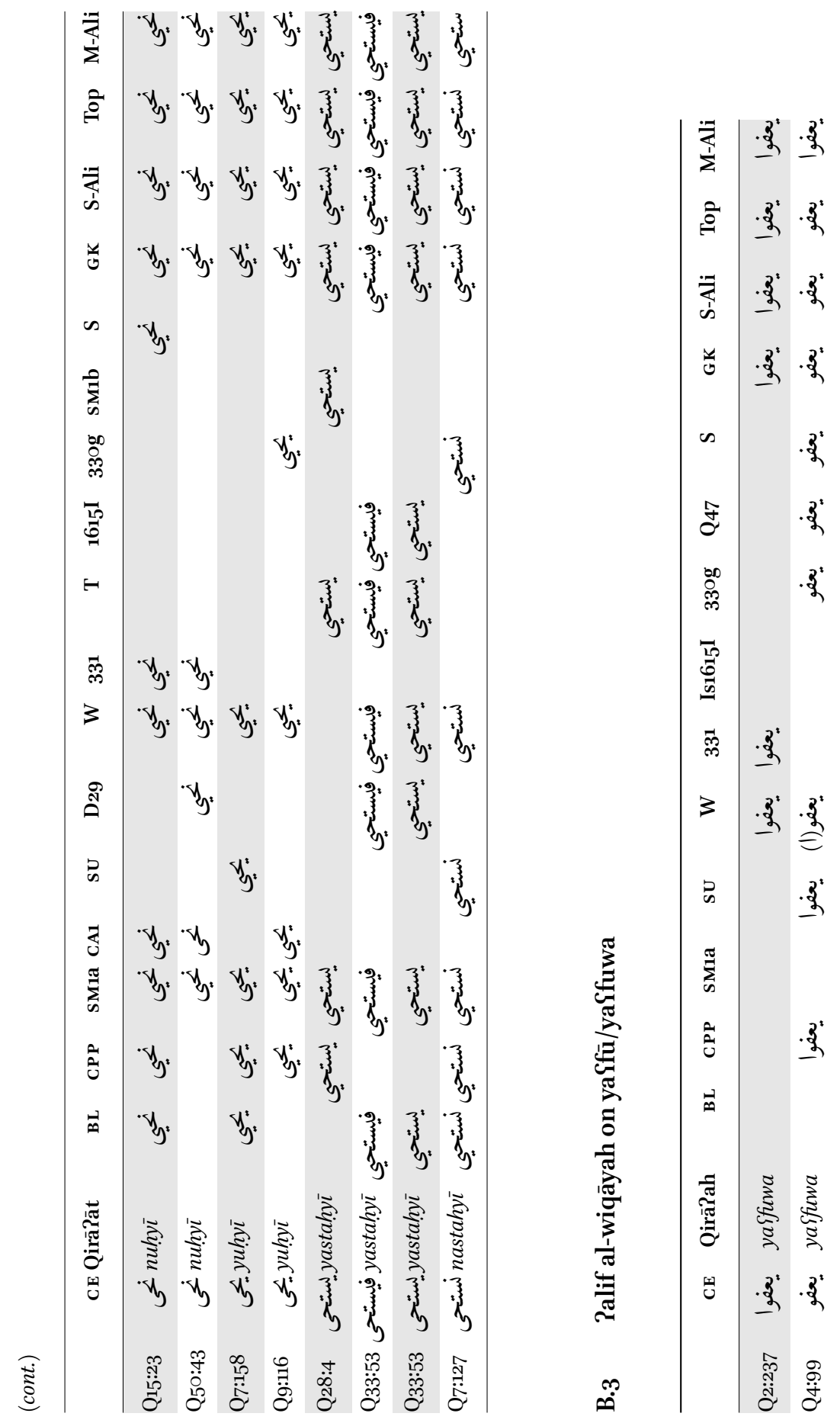

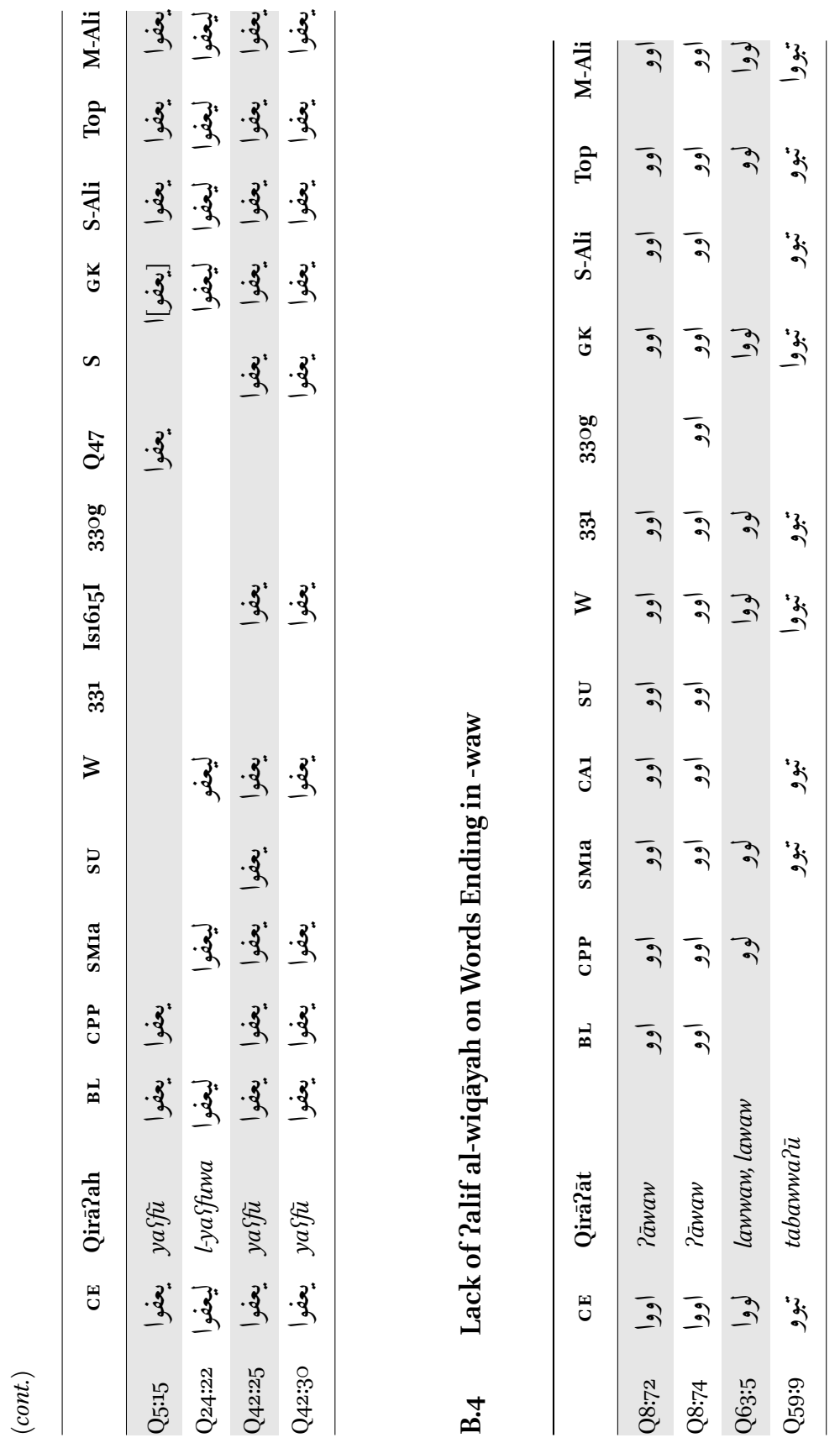


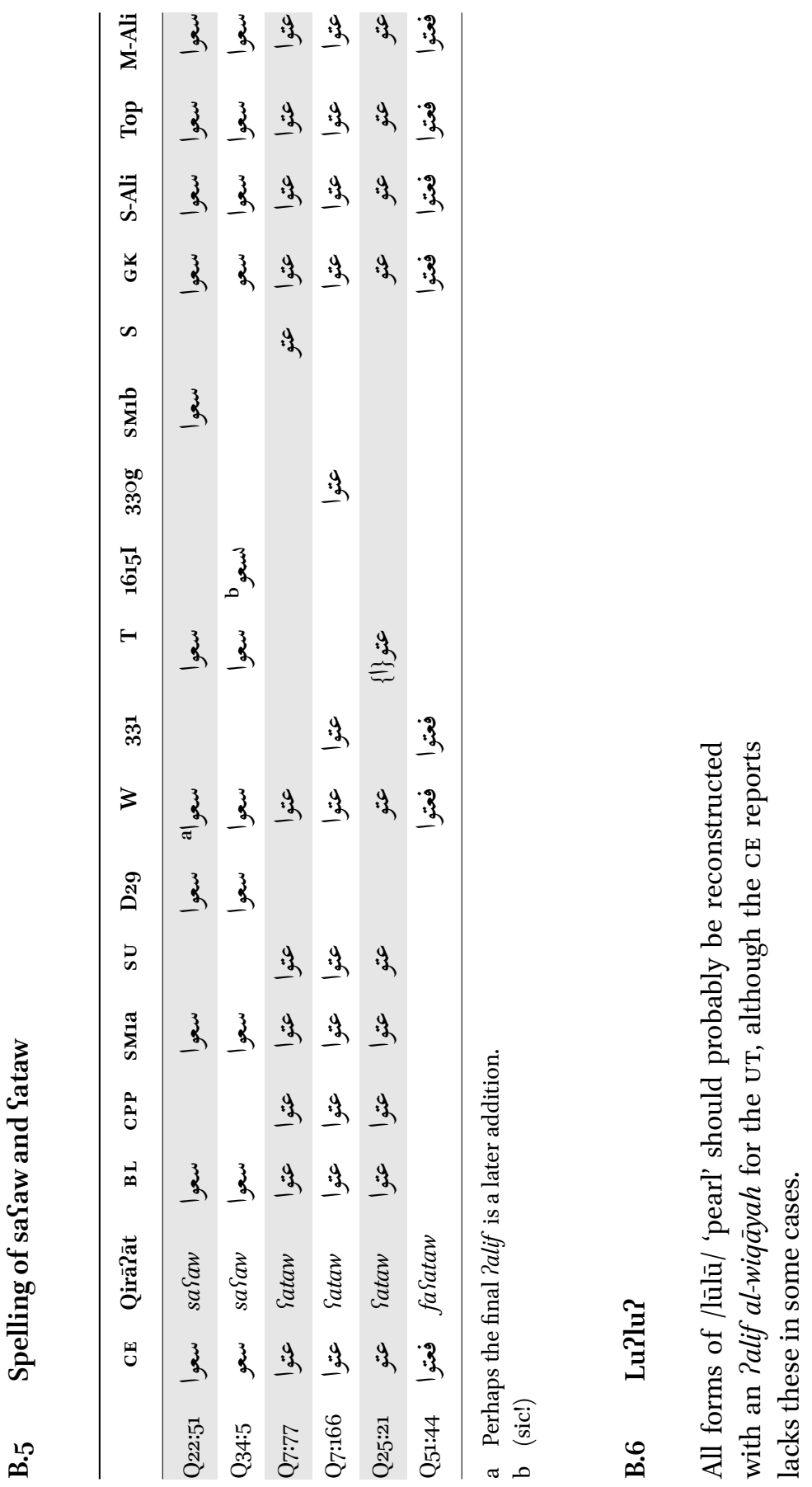



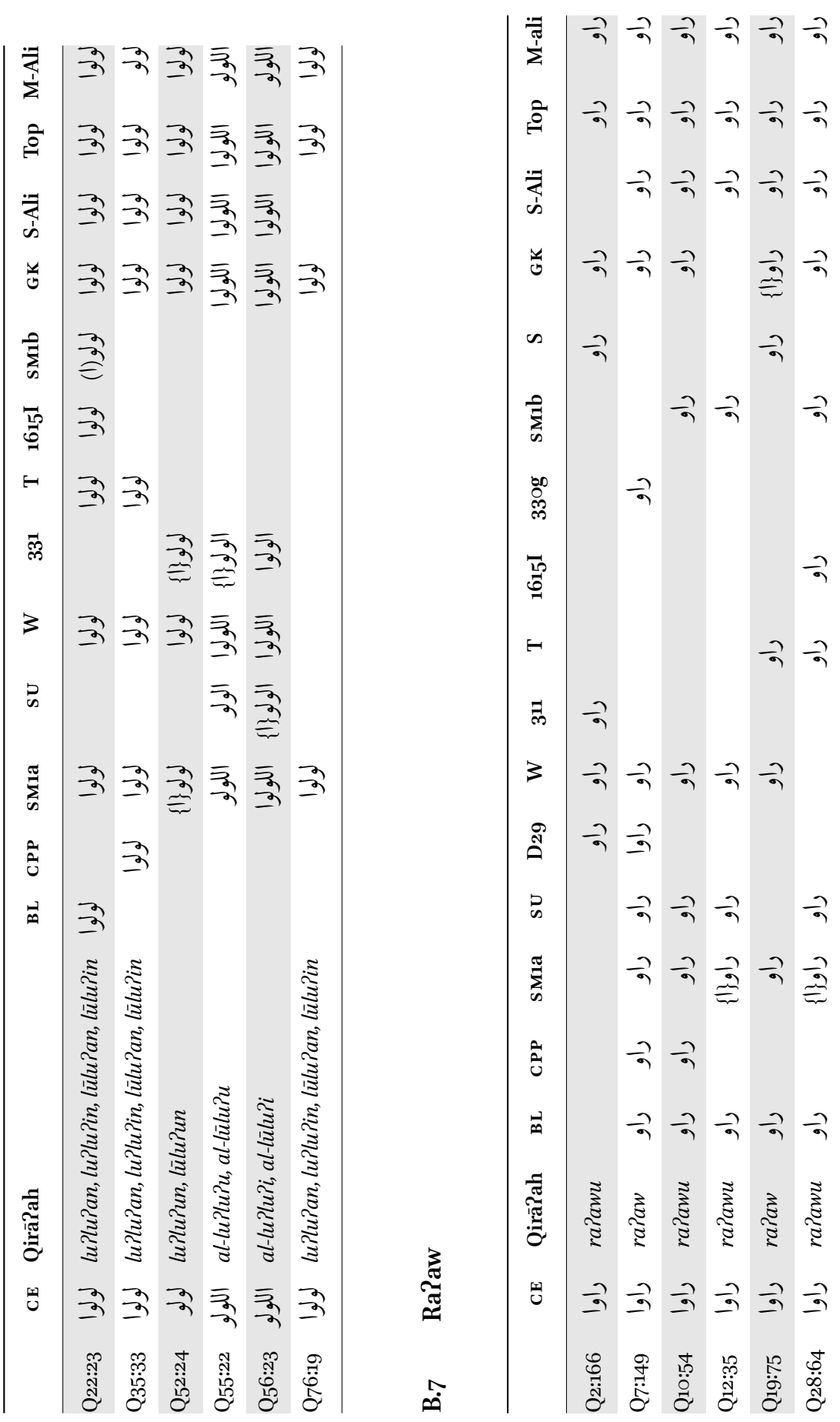

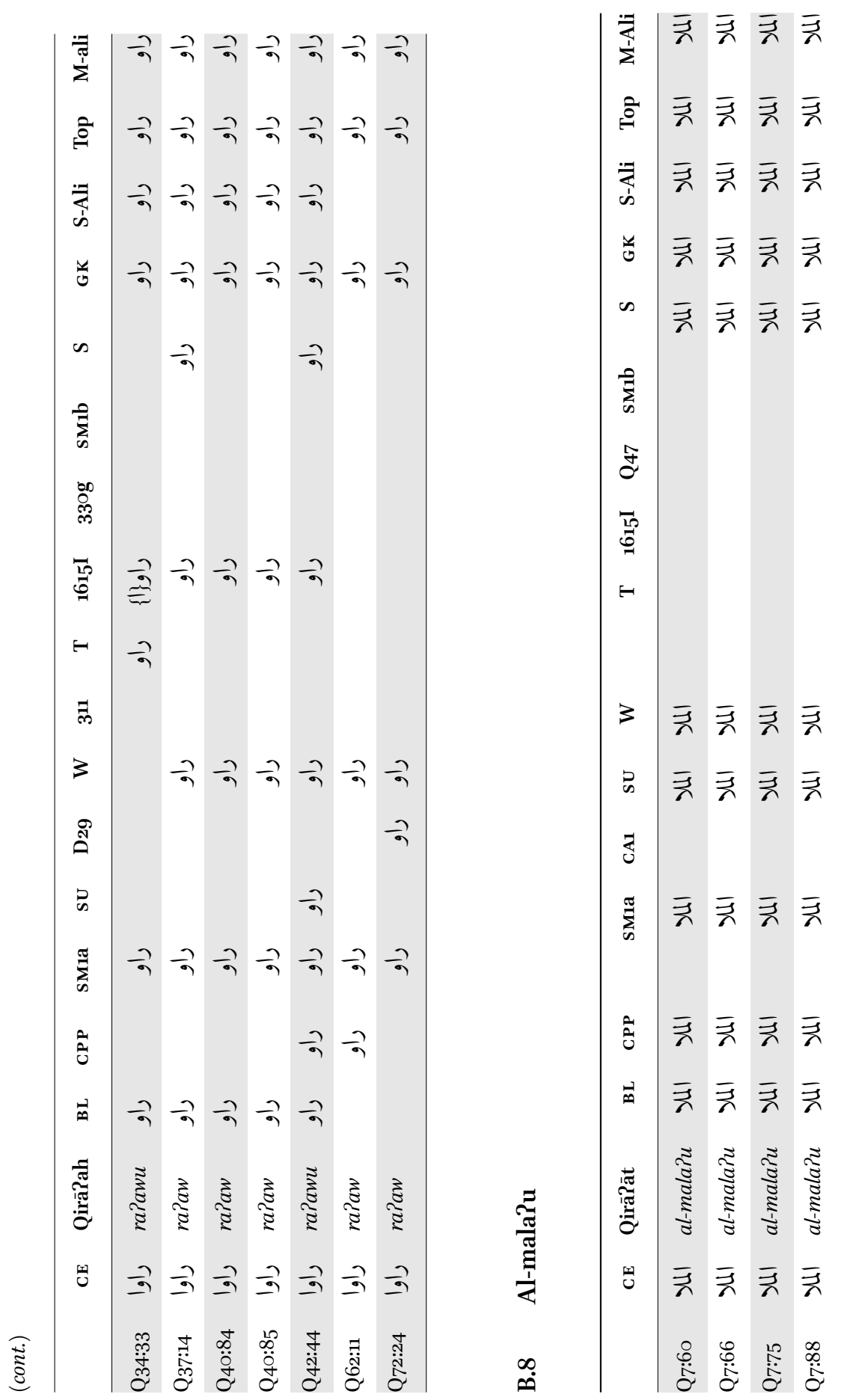


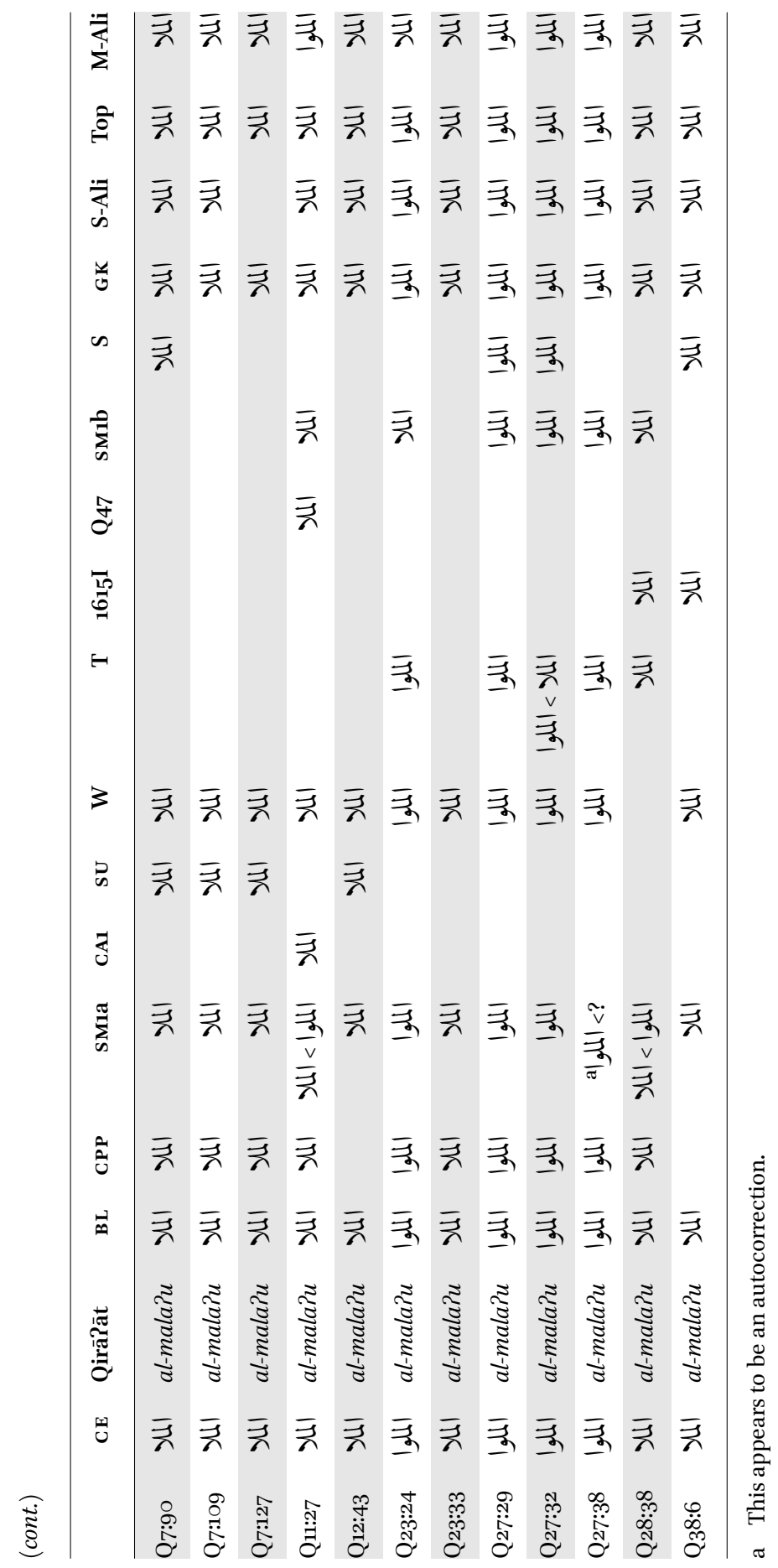



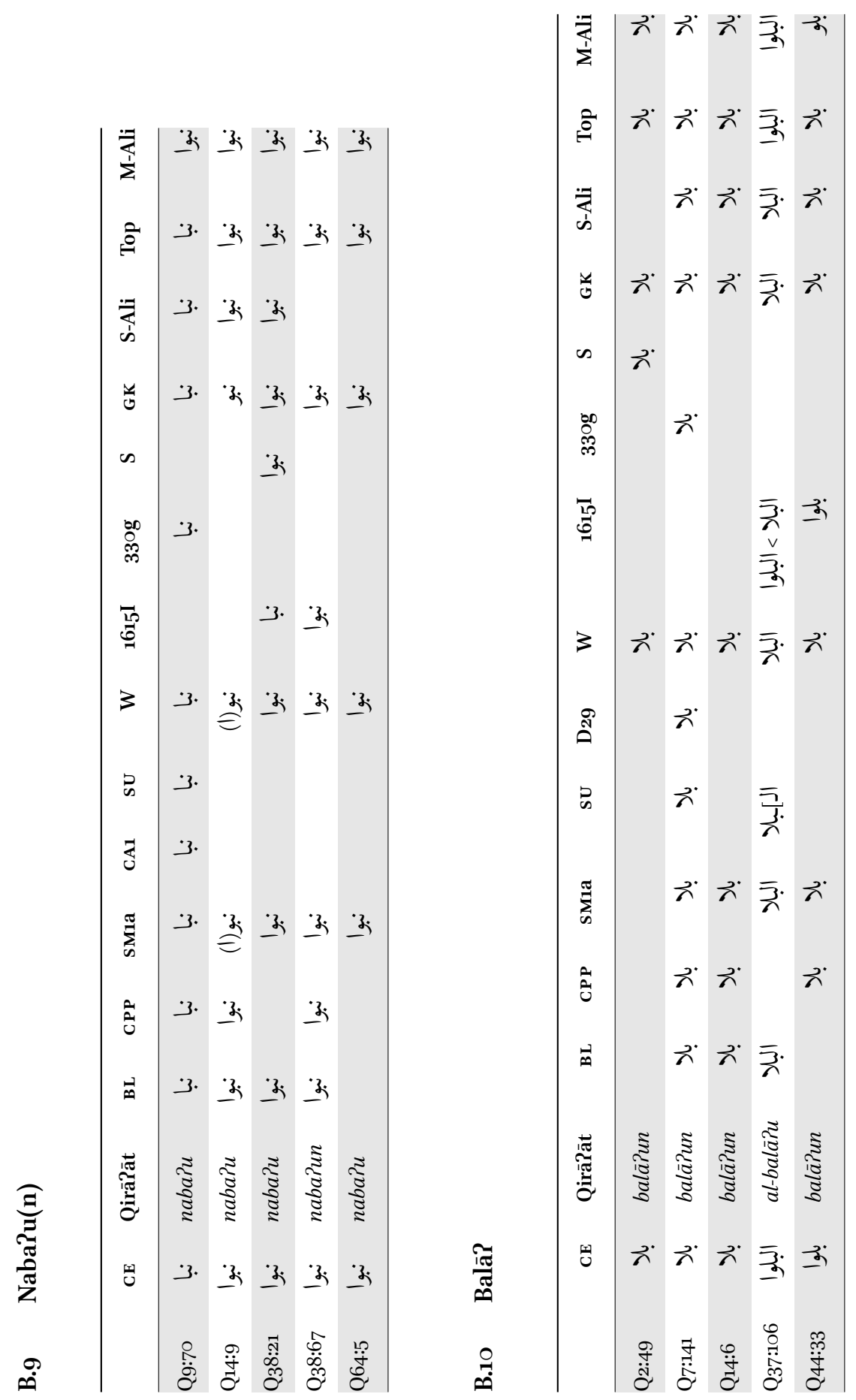


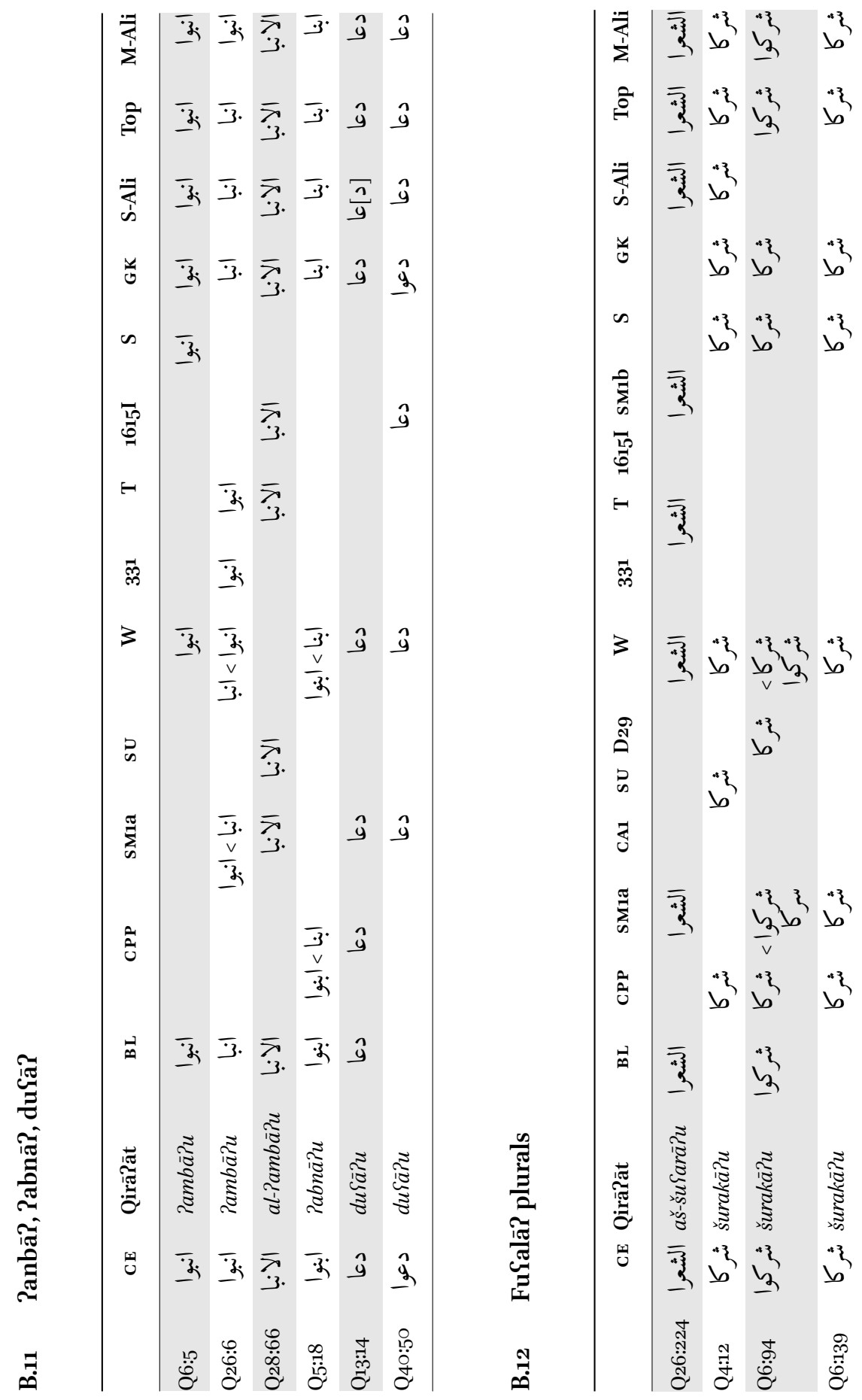




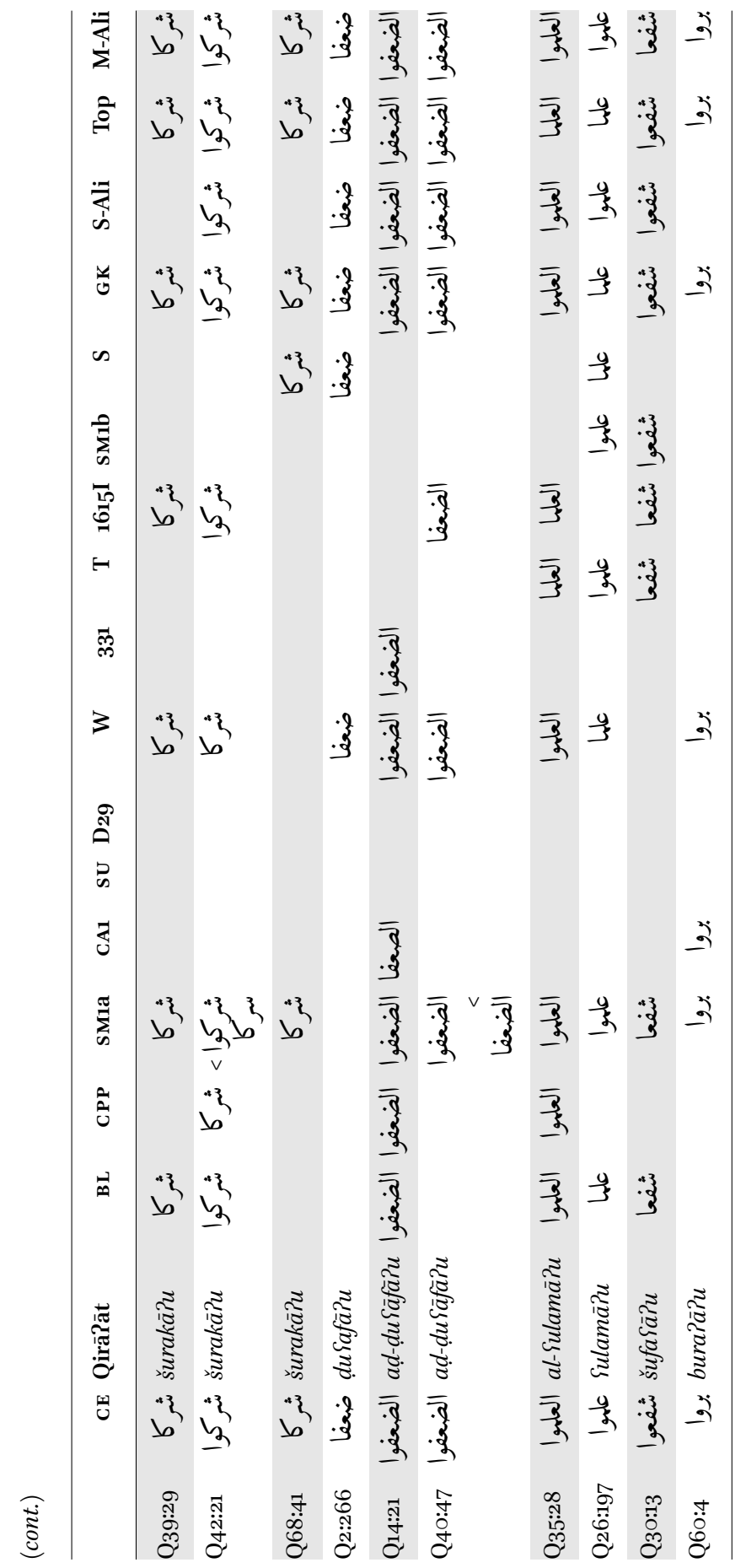




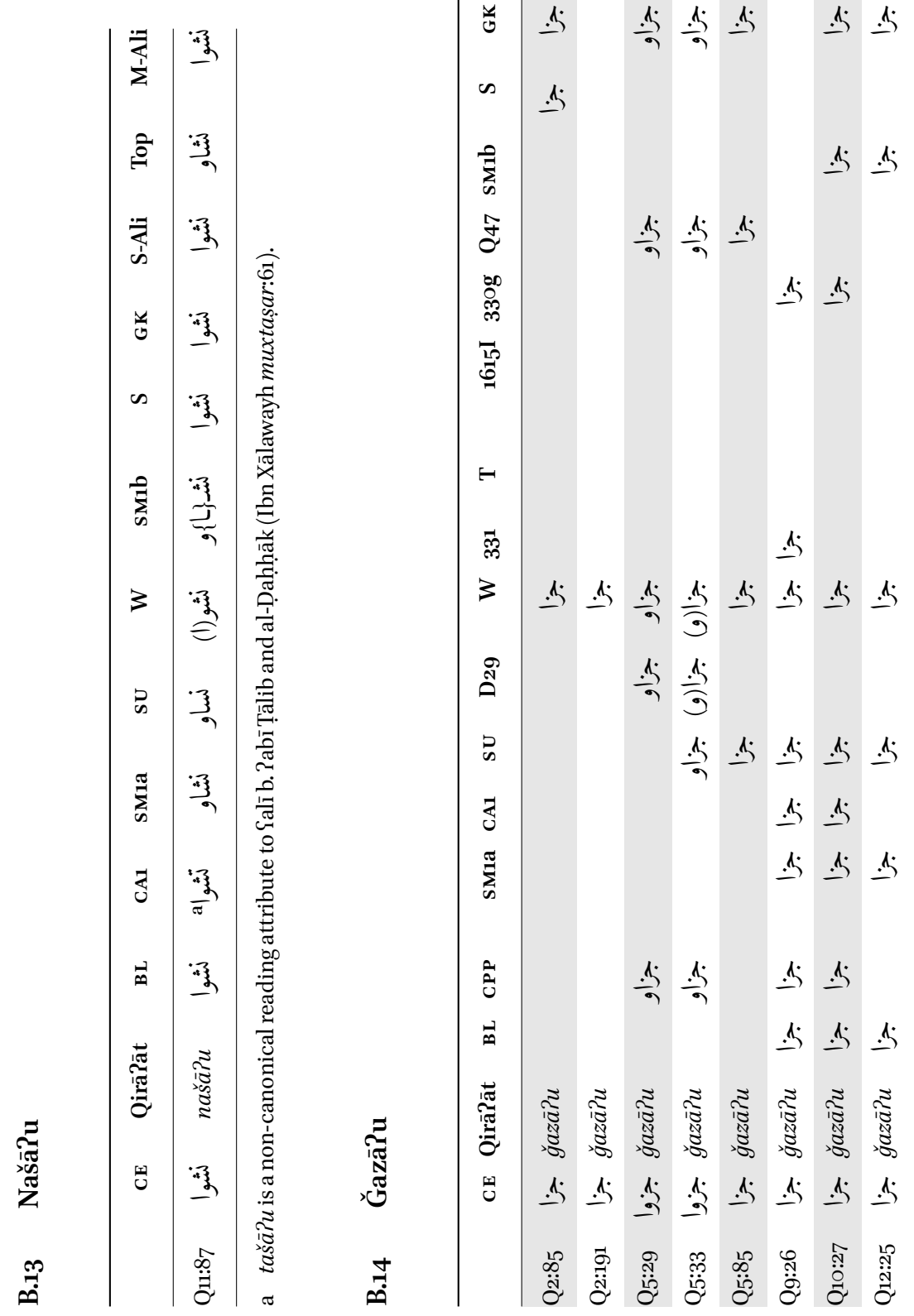




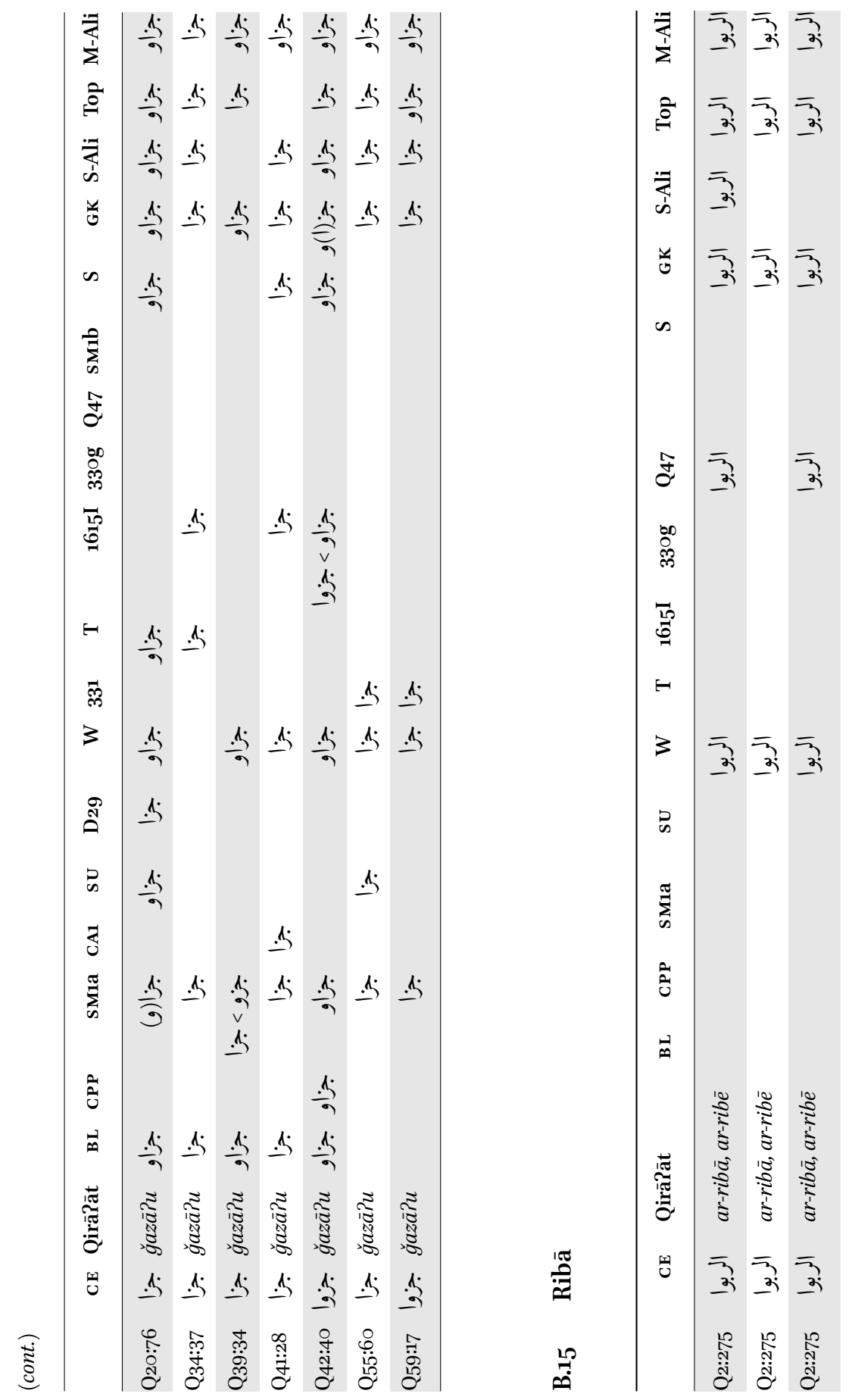




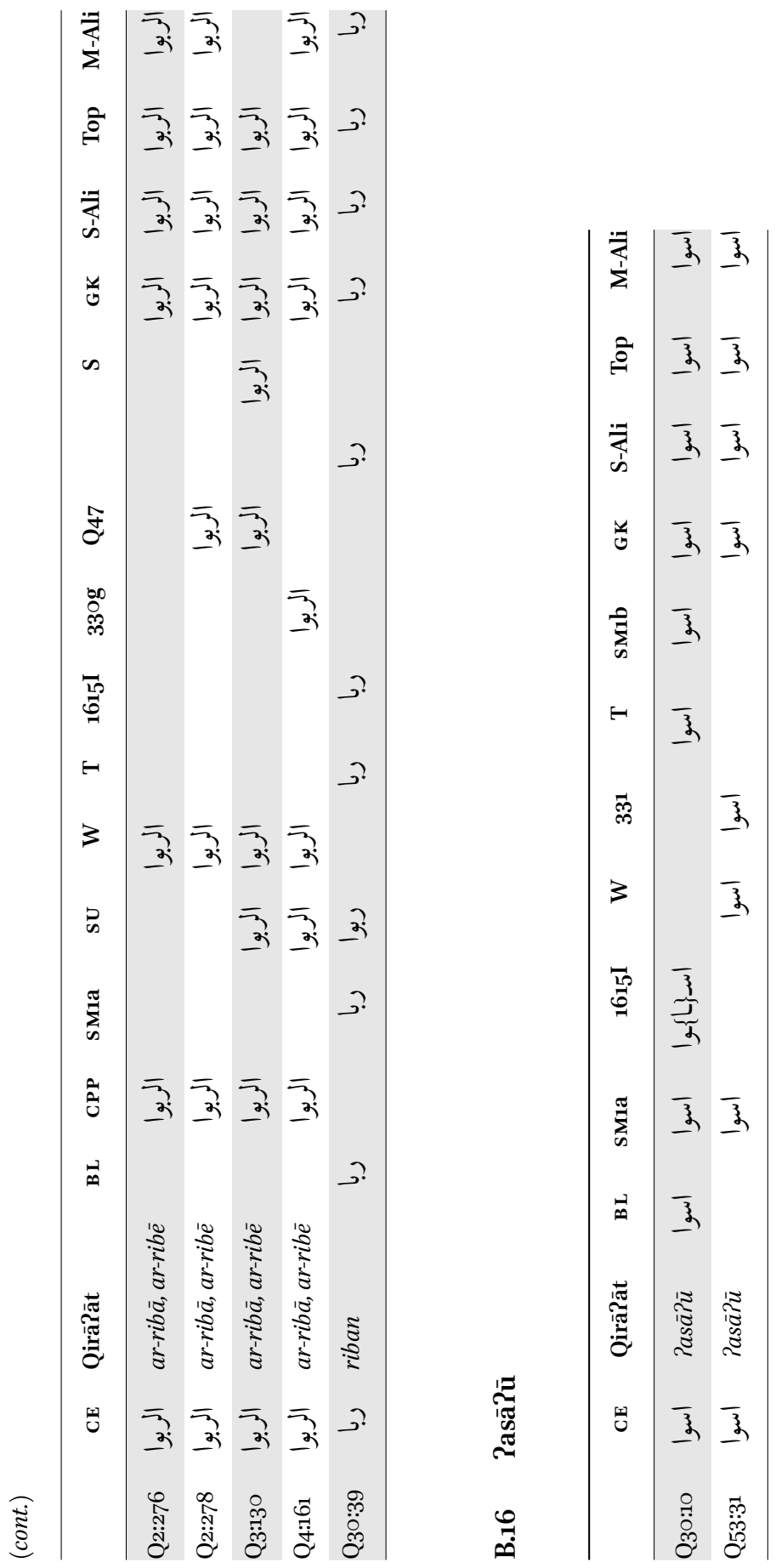




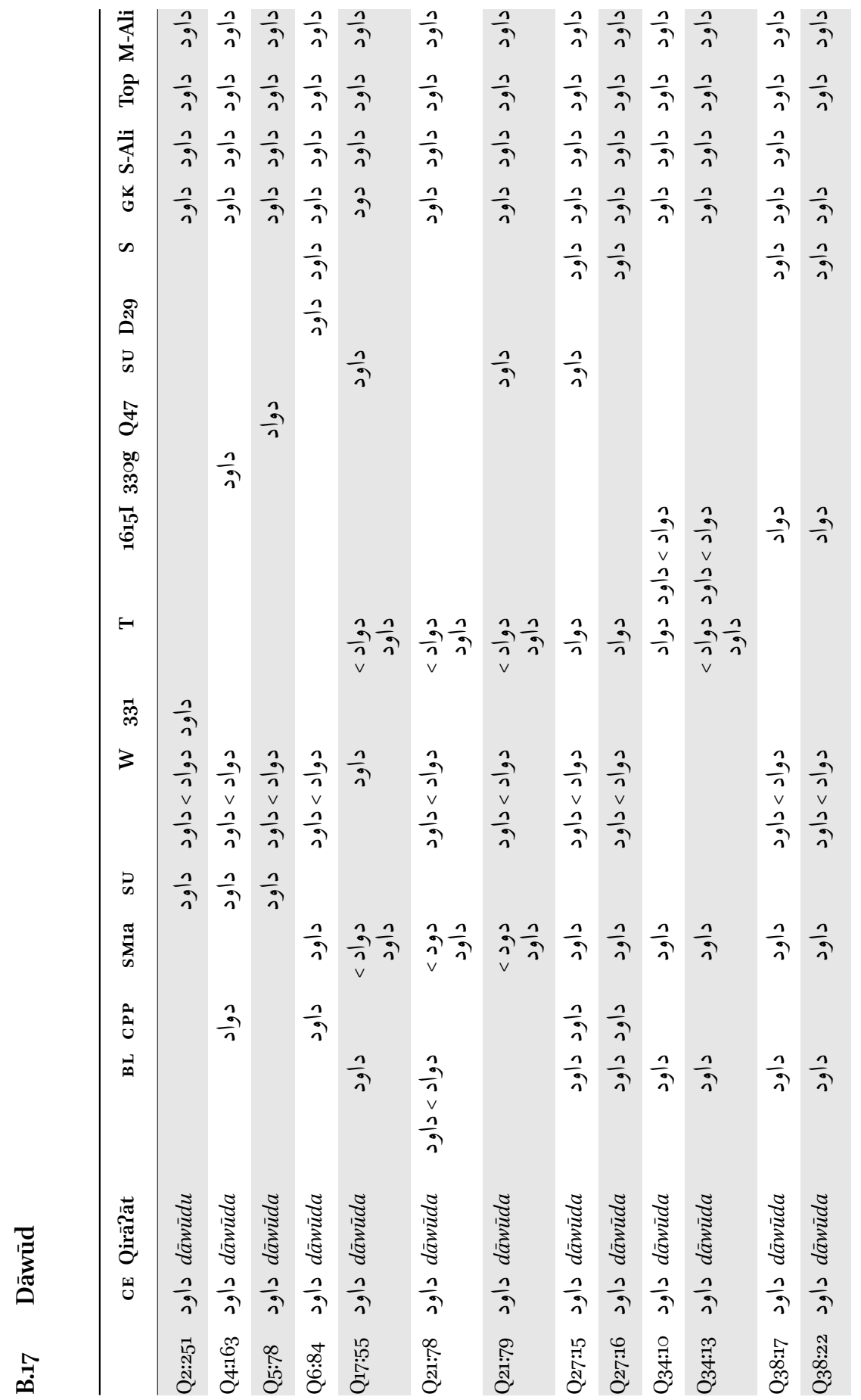



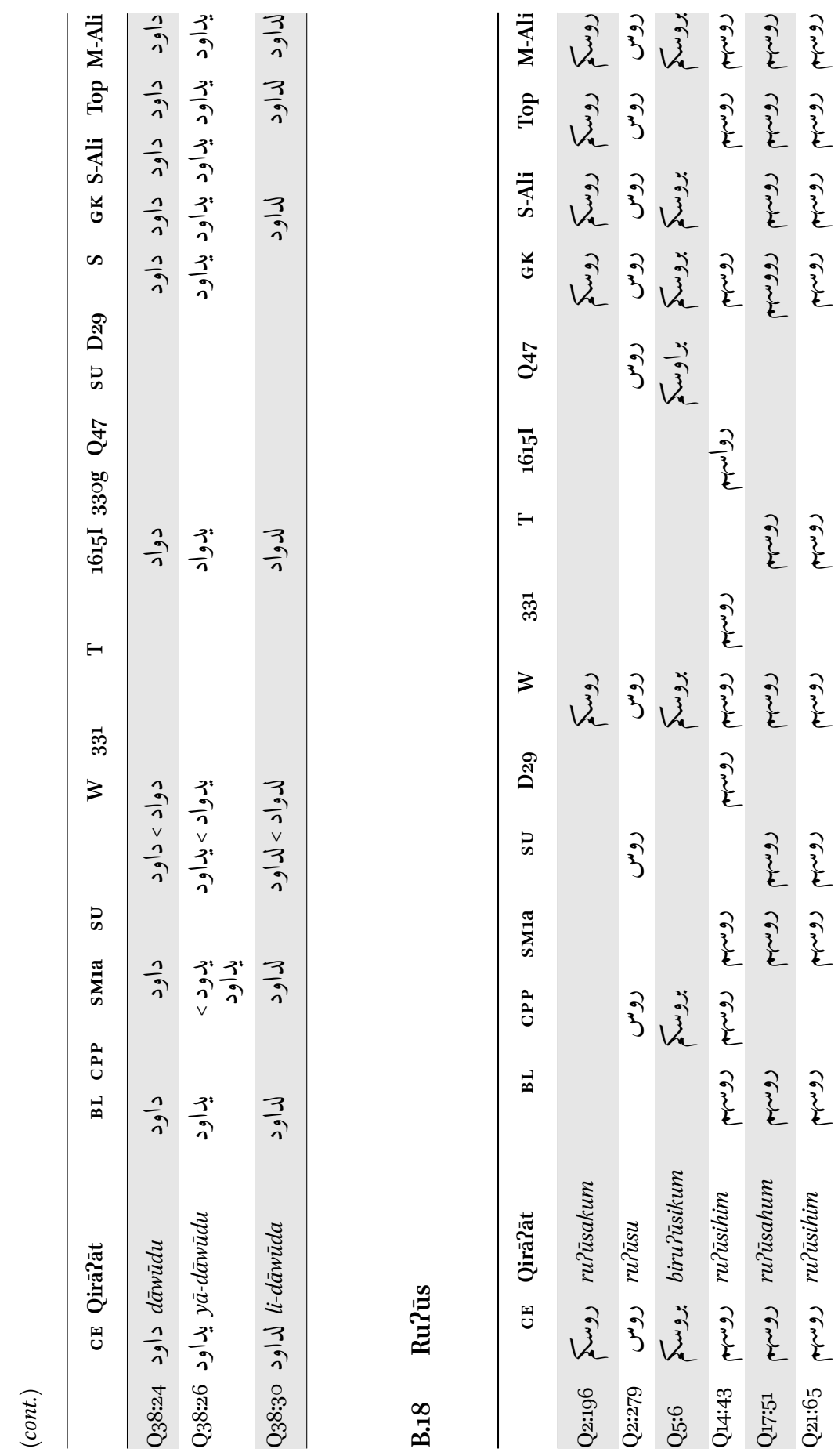


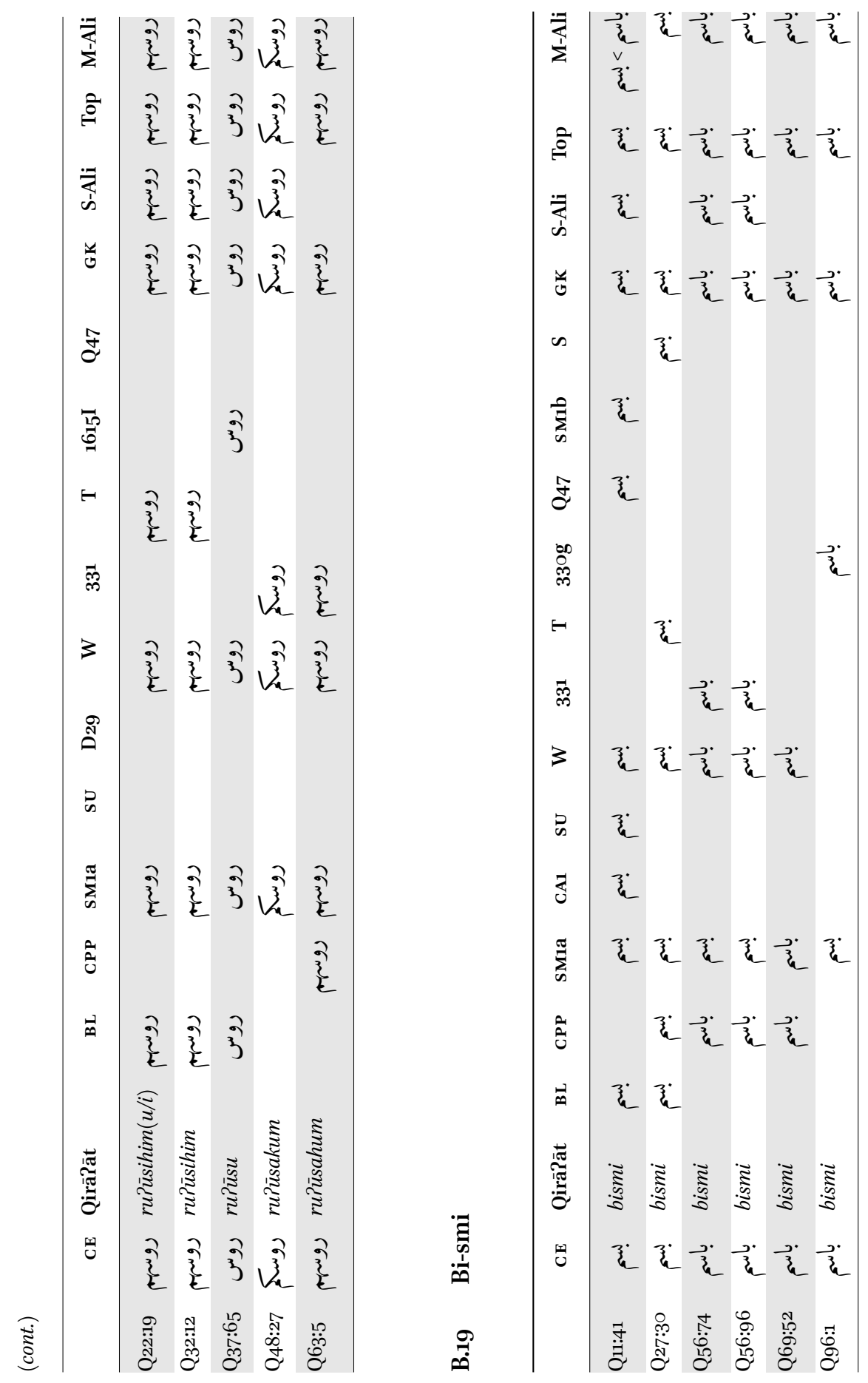



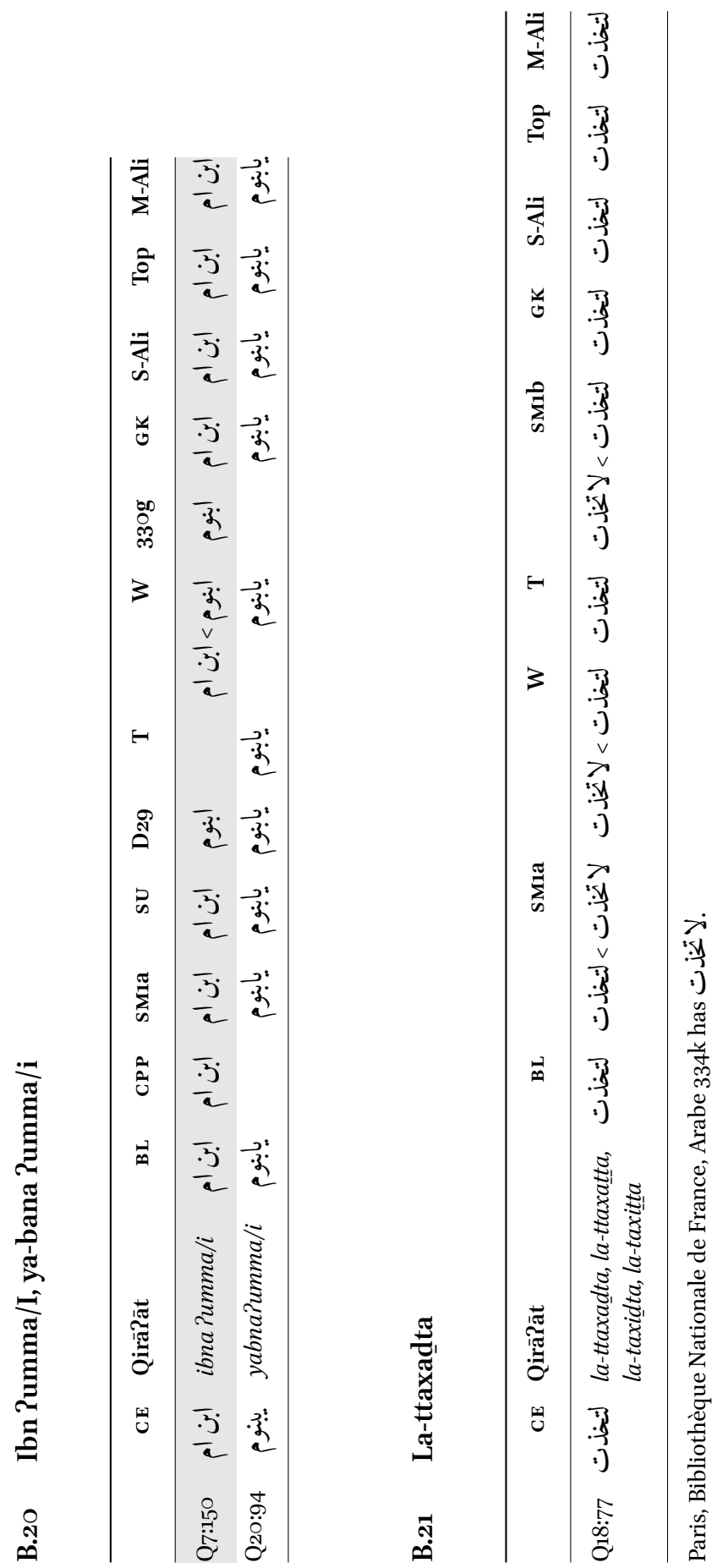


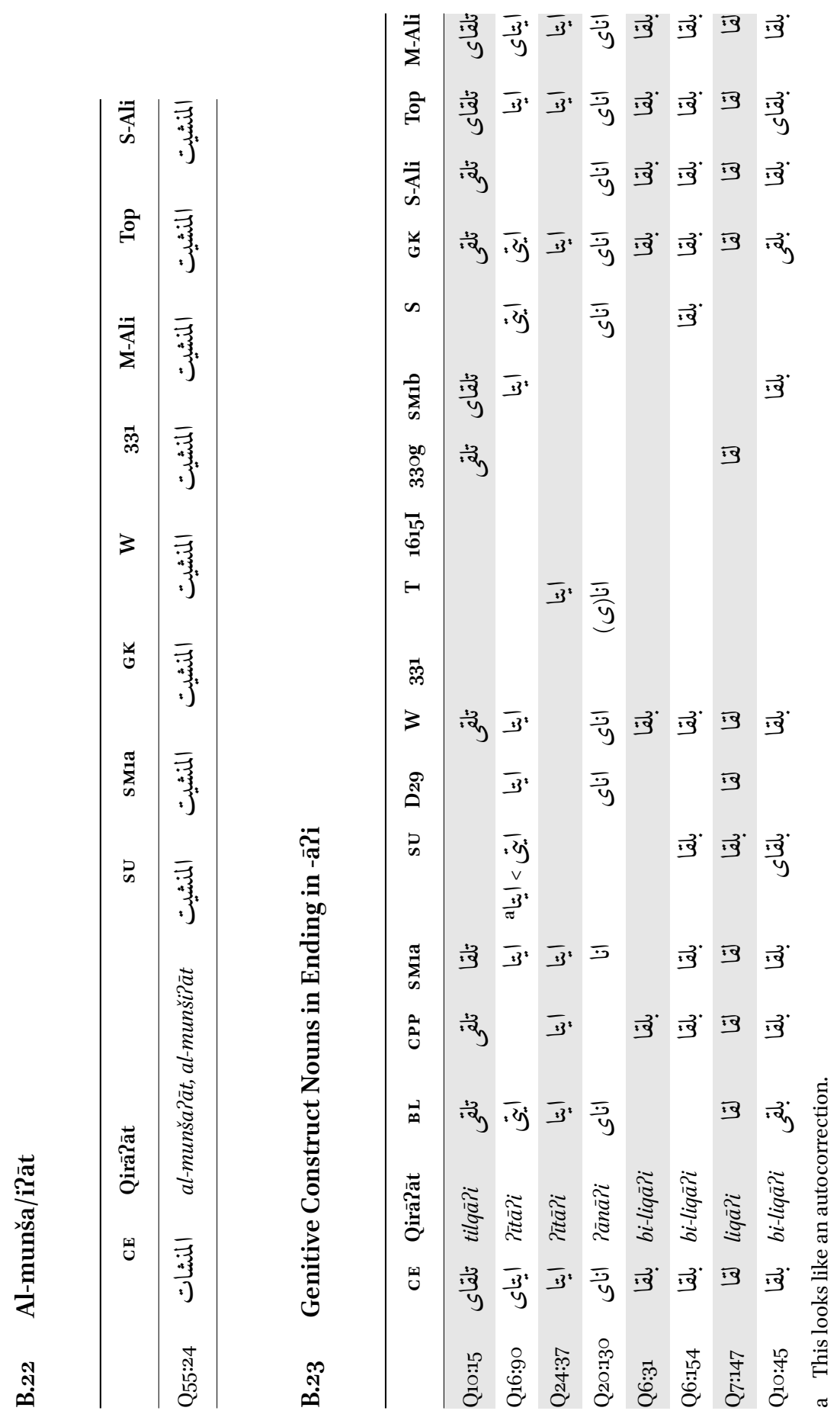




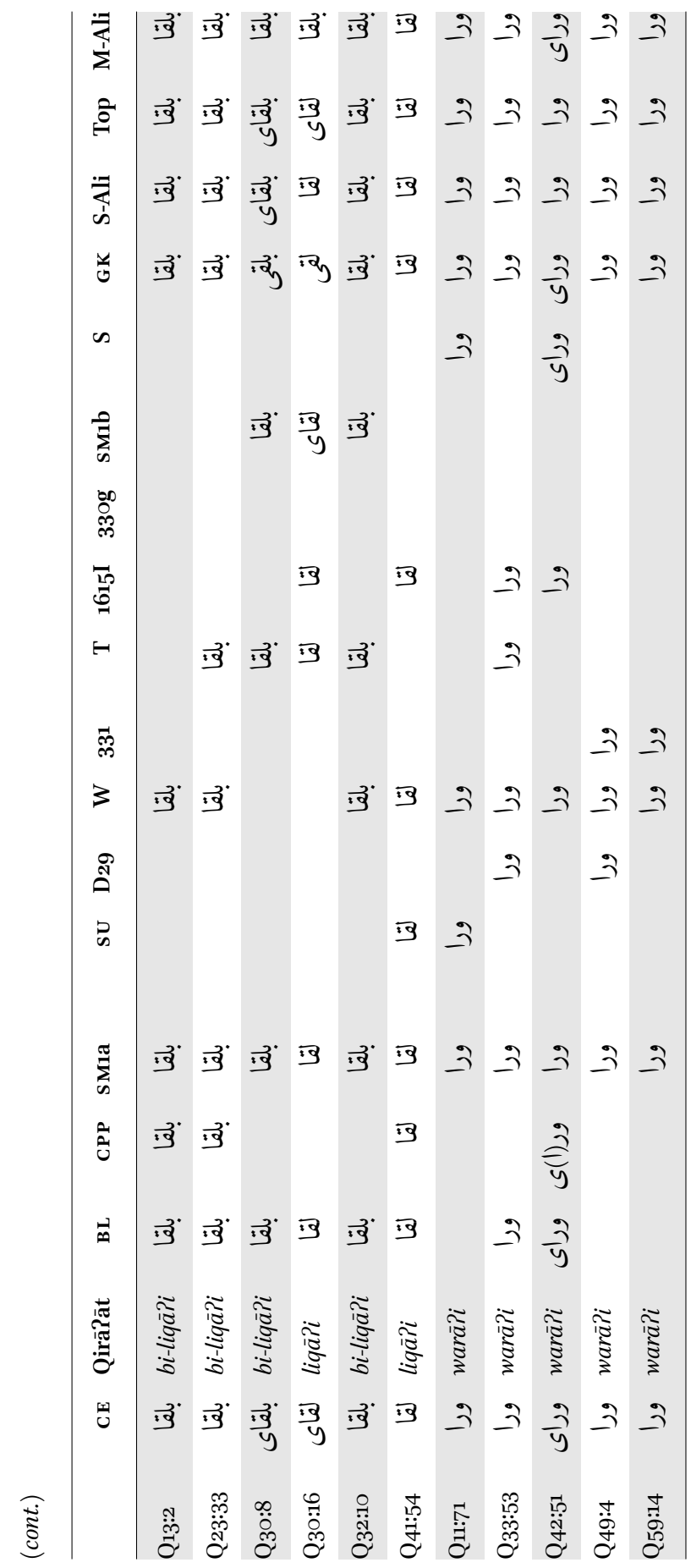




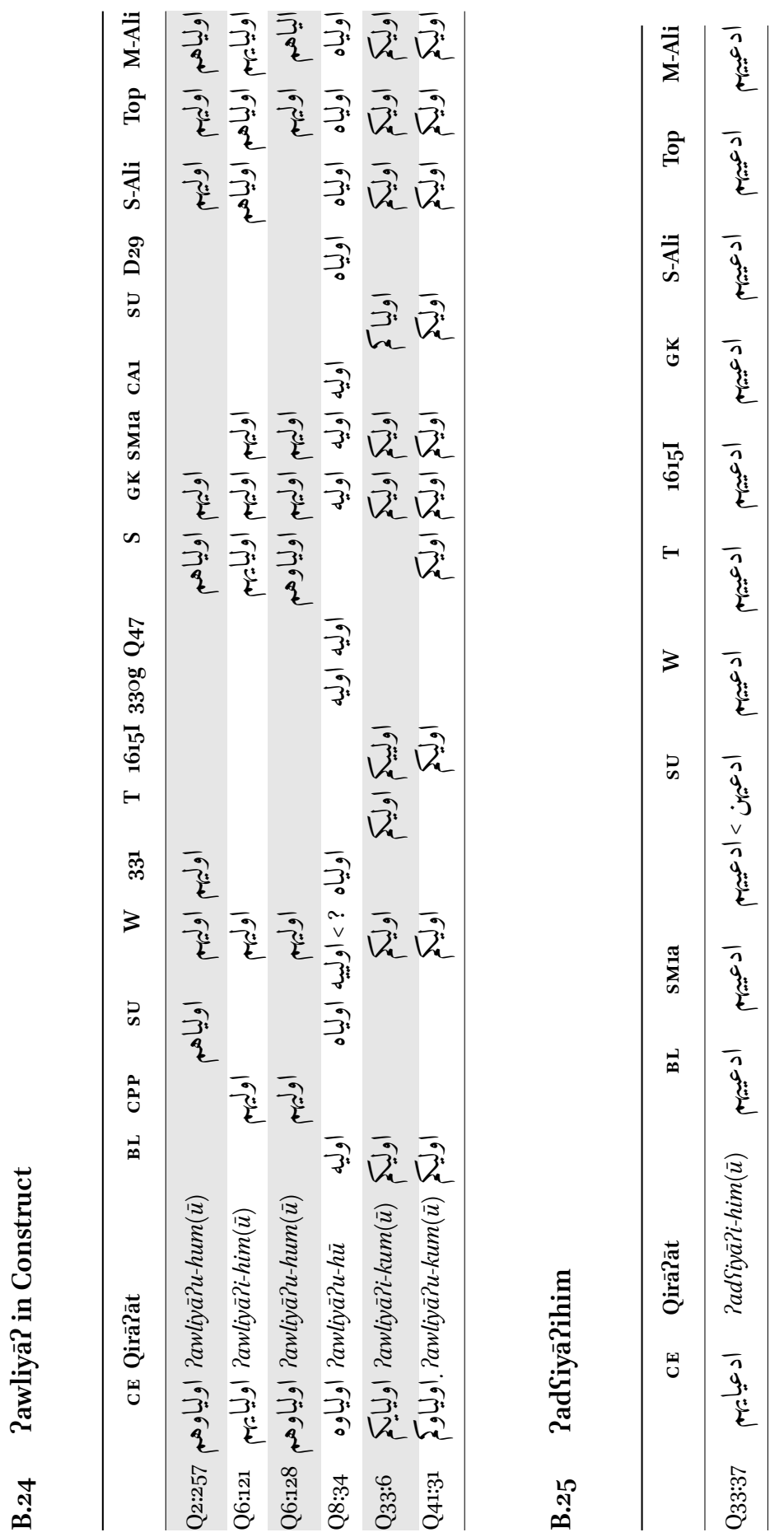




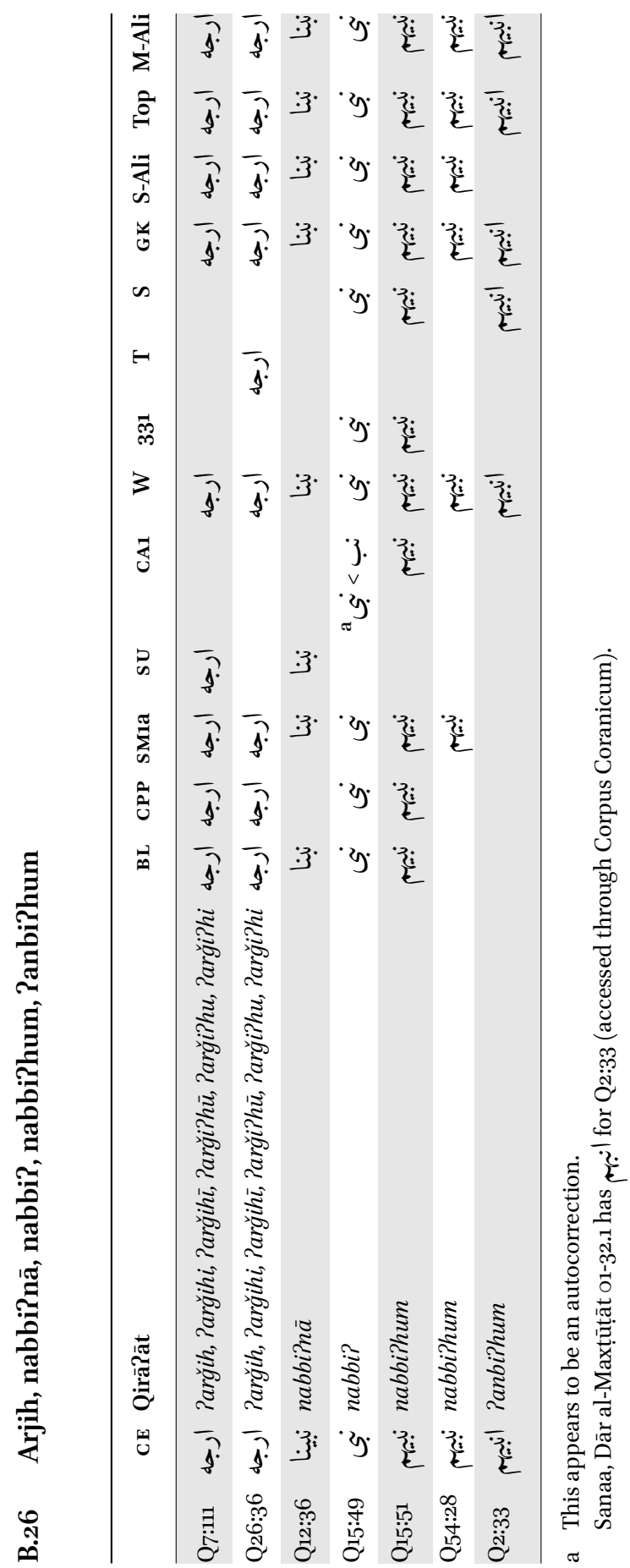



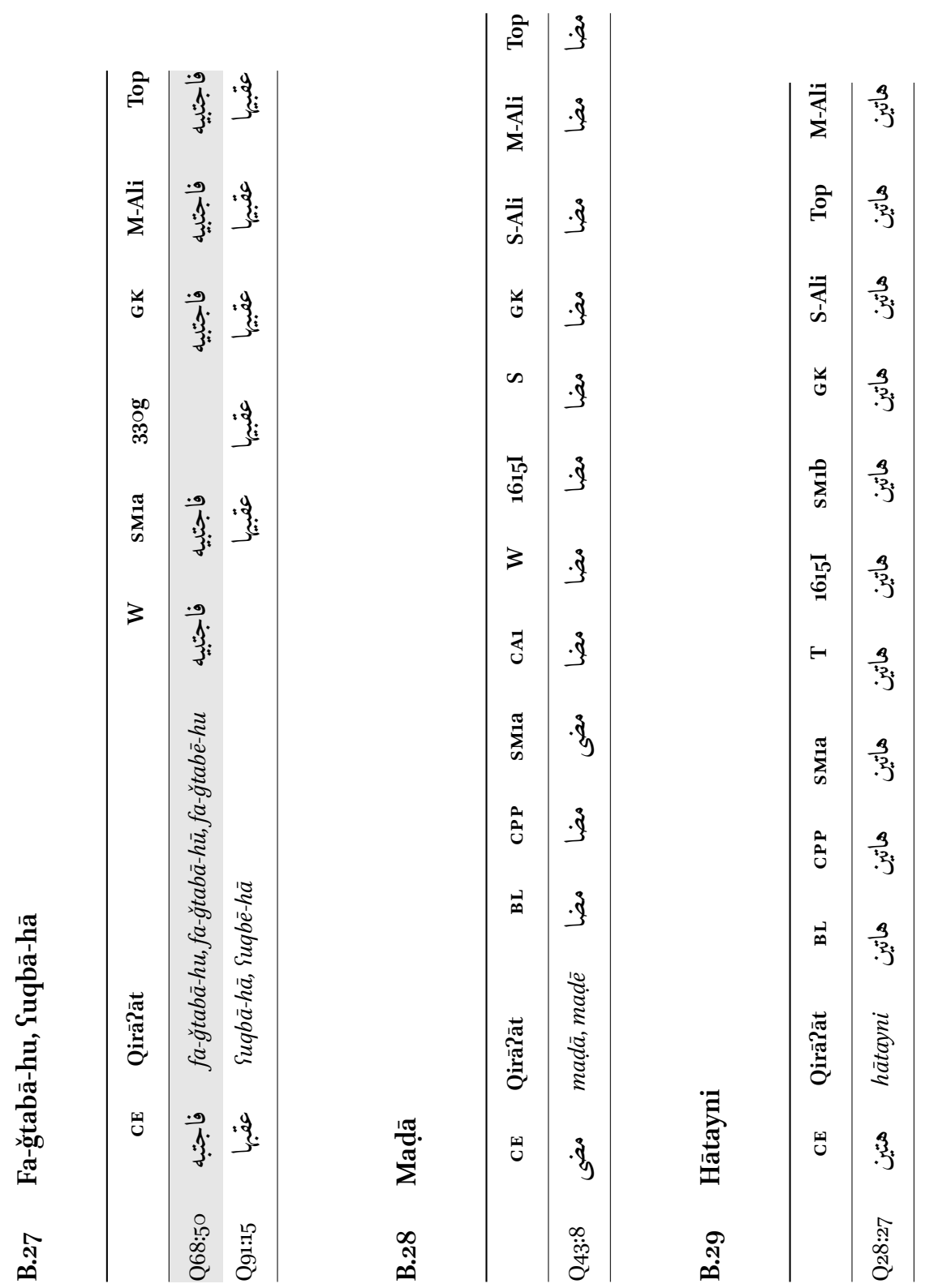